The International Journal of Banking and Finance, Volume 10 (Number 1), 2013: Pages 57-73

\title{
ECONOMIC FREEDOM, MACROECONOMIC FUNDAMENTALS AND FOREIGN DIRECT INVESTMENT IN FAST EMERGING BRICS AND MALAYSIA
}

\author{
Catherine S. F. Ho, Noryati Ahmad and Hayati Mohd Dahan \\ Univeristi Teknologi MARA, Malaysia
}

\begin{abstract}
This study investigates the major factors that determine the inflow of foreign direct investment (FDI) into fast emerging countries: Brazil, China, India, Russia, South Africa (BRICS) and Malaysia. Two sets of factors are identified: macroeconomic and country specific fundamentals. The period of analysis is 1977-2010. The study provides empirical evidence that economic growth, government consumption and trade openness are vital for FDI. In addition, country specific infrastructure quality and economic freedom are also critical factors in determining FDI for this group of countries. Our findings have significant policy implications for the growth and development of these countries, particularly through foreign direct investments.
\end{abstract}

Keywords: FDI, Trade openness, Economic freedom, Macroeconomic fundamentals

JEL Classification: F21, F31, F41, F43.

\section{Introduction}

The global economy has experienced unprecedented paradigm shifts in the last decade. Coupled with the recent crises in developed regions, it may be timely for emerging economies to fill the vacuum of growth left vacant by developed countries in order to drive world economic development. Despite decades of civil unrest, political and economic turmoil overshadowing some of these countries, there are strong indications that economic development is fast growing in these regions. Although still unable to free themselves from the shackles of corruption and poverty, the success of these economies currently rests on their ability to attract foreign direct investments from developed and developing countries.

Trade between BRICS countries and the rest of the world has grown significantly with China and Brazil being the world's fastest growing economies. These countries are set to improve their economies by developing infrastructure, agriculture, manufacturing and the development of small businesses. Ranked as the poorest continents in the world, Latin America and Africa have posted 
strong growth rates in recent years, drawing increasing inward investment. Despite a projected much faster gross domestic product (GDP) for these countries, a more optimistic prospect compared to the debt-ridden economies of the west, BRICS countries should not take a backseat in terms of creating opportunities for trade and investment.

Foreign direct investment (FDI) has come to play a major role in the internationalization of business in the past decades. Lokesha and Leelavathy (2012) defined FDI as the process whereby domestic investors of home country acquire assets for the intention of controlling all the activities of the firm which is located outside the country. Changes in technology coupled with growing liberalization of the national regulatory framework governing investment in enterprises and changes in capital markets have led to profound changes in the size, scope and method of FDI. Foreign investment usually brings along capital inflows as investments in long-term assets contributing to higher aggregate demand of the economy and therefore eventual growth. Corporations within the country tend to be more productive to effectively counter the threat of the competition from abroad brought about by FDI. This contributes to the growth of a country's income and employment, another positive effect of FDI when a country becomes more productive. Employment is also created with increased productivity and competitiveness. New informational technological systems and the decline in global communication costs have also made management of foreign investments far more effective than in the past.

Changes in trade and investment policies as well as the regulatory environment such as trade and tariff liberalization, easing of restrictions on foreign investment and acquisition, plus the deregulation and privatization of many industries have been significant vehicles for expansion of FDI across the globe. The recent global financial crisis and the previous financial crises in Asia and Latin America resulted in relying on FDI in order to supplement national savings and promote economic development. Emerging economies derive benefits from foreign investments to improve their balance of payments, increase exports to earn more hard currencies, reduce imports to save more of their hard currencies, increase employment to improve their fiscal position, and enhance their access to newer technologies.

This study investigates the relations between macroeconomic fundamentals, country specific factors and FDI in fast emerging BRICS countries. Understanding the drivers of foreign investments would provide authorities in respective fast emerging countries with vital information on policy decisions that would enable them to accelerate growth and eliminate poverty. The set of fast emerging countries included in the study are Brazil, Russia, India, China, South Africa and Malaysia. The major factors that are considered are divided into two sets: macroeconomic fundamentals consisting of market size, trade openness, financial depth, exchange rate, government consumption, inflation rate, 
interest rate; and country specific factors of economic freedom, employment, literacy rate and infrastructure quality.

\section{Prior Empirical Evidence}

This section provides some historical analyses of FDI for the countries considered. It also details prior empirical evidence on variables that are relevant to emerging countries but may not yet been commonly researched, for instance, economic freedom, financial development, and trade openness.

\section{A. FDI in BRICS and Malaysia}

Vijayakumar and Sridharan (2010) conclude that emerging Brazil, Russia, India, China and South Africa (BRICS) economies exhibit economic strength in the face of the U.S. credit turmoil and growth slowdown by their strong domestic demand growth. Three countries -- Brazil, India and South Africa -- attracted FDI due to their demographic trends, labor supply dynamics and low urbanization ratios. There is a huge potential for economic growth in these countries and it would exert competition and challenges towards developed countries. The current flow of FDI into BRICS is extremely intricate and competitive, both in the home and host countries. This study therefore intends to examine if macroeconomic fundamentals, economic freedom and other major determinants are significant in affecting FDI flows into Malaysia and BRICS countries.

Foreign investors are currently looking into new markets with vast changes in trade and investment preferences. Countries including Brazil, Russia, China, India and South Africa are currently the new FDI destinations. These countries offer not only an enormous untapped market but also much lower production costs, especially labor. The availability of human capital, infrastructure as well as skills and education are factors that attract investors to these countries.

Recent developments in Malaysia show a decline in FDI inflows from 2006 to 2009 (Figure 1). The country has lost some of its attractiveness from foreign investors to neighboring countries like China and India due to the shortage of human capital and pressure on wages. It is believed that Malaysia still has the ability to improve economically by enhancing and stimulating its domestic economy. Other parts of the world including China, Russia and India are attracting vast amount of FDI (Figure 2). Many factors may have affected FDI to these countries and their identification and analysis are the aims of this paper. 
Figure 1: FDI Inflows for South Africa and Malaysia

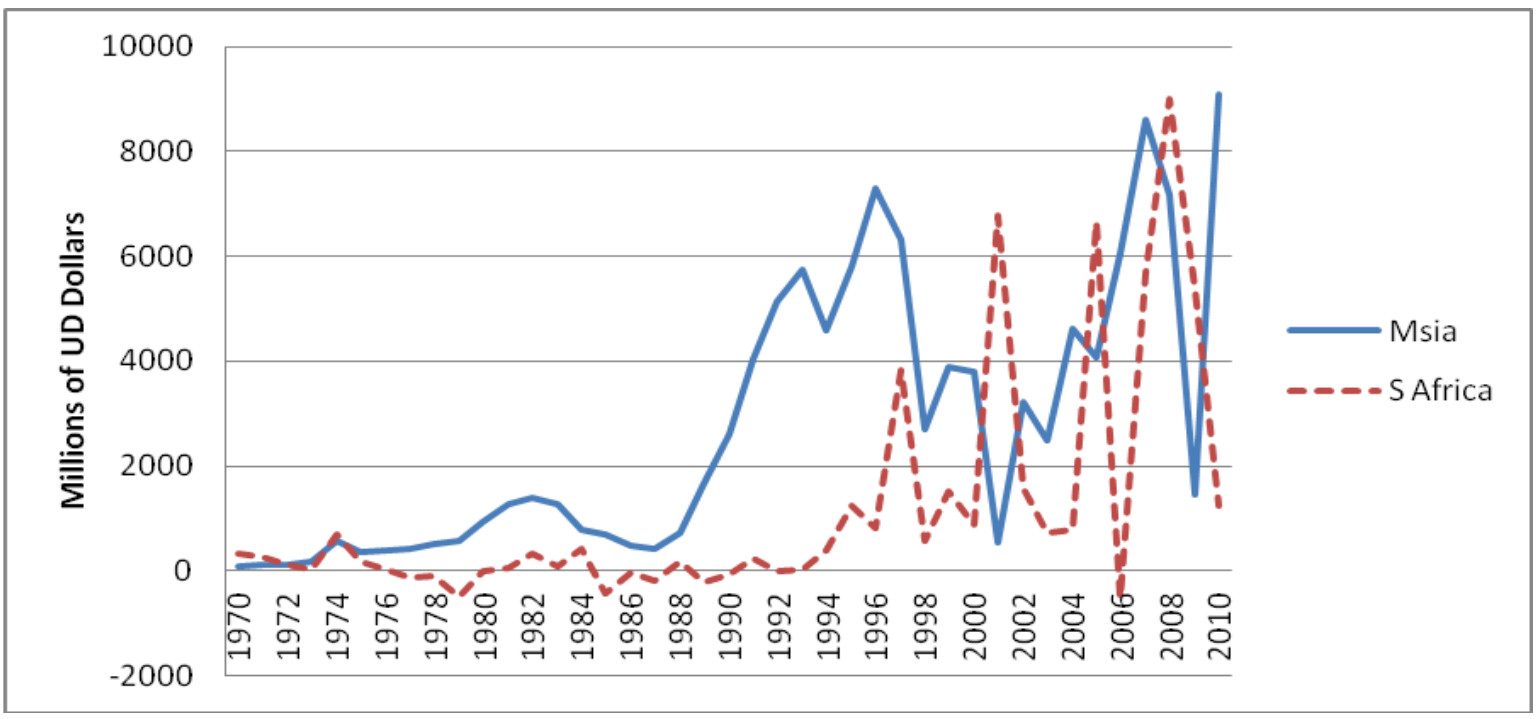

Source: UNCTAD

Figure 2: FDI Inflows for Brazil, Russia, India and China

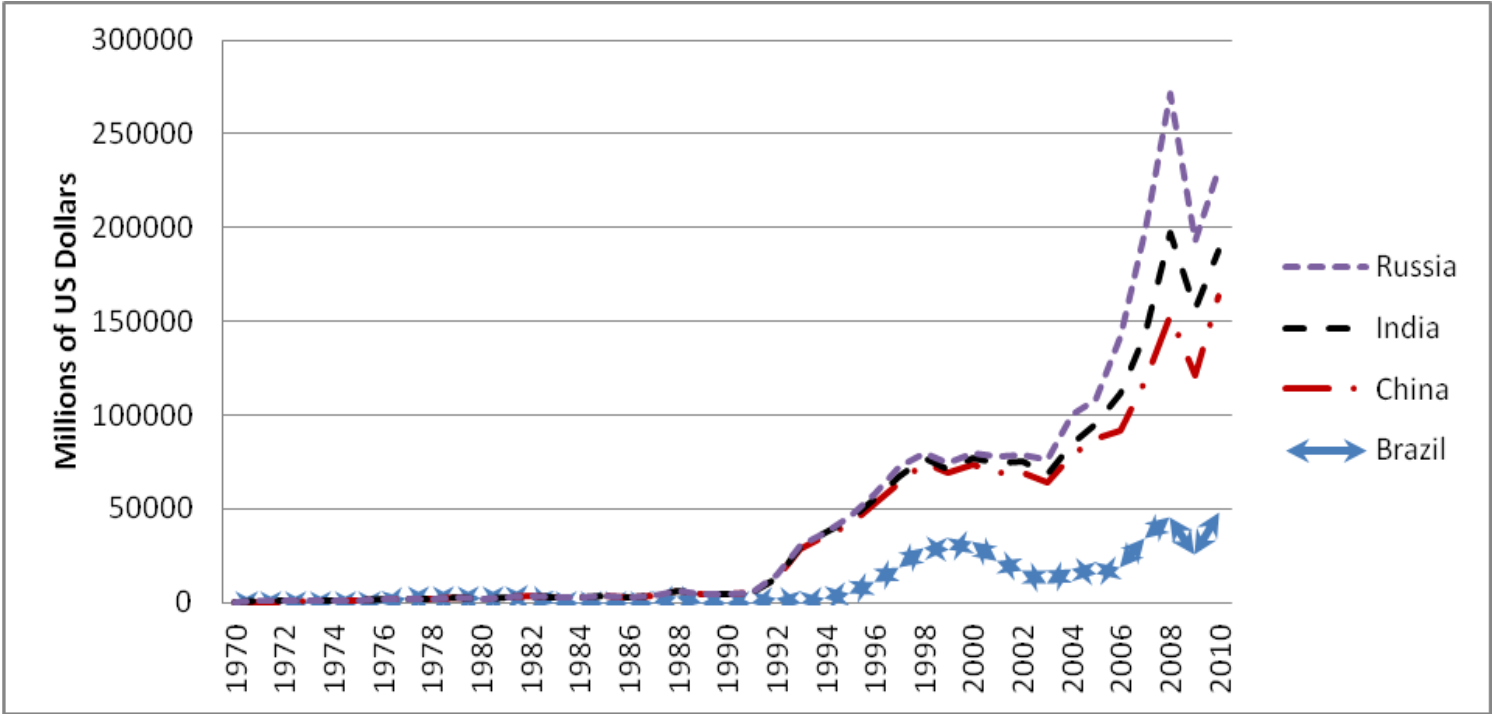

Source: UNCTAD.

\section{B. Macroeconomic Fundamentals}

This section, as well as the next one, provides historical support for major variables that are considered important in determining FDI. We rely mainly on the findings in prior contributions.

Investment return and profits in developing countries are directly affected by market size and its growth. Higher rate of market growth indicates potential for a larger market and more promising prospects for products produced. Market size is thereby considered as one of the most important determinants for horizontal market-seeking FDI. Zhang (2001) shows that market size and 
infrastructure are key factors in attracting foreign investments. Duanmu and Guney (2009) find similar results for China and India where FDI into both countries are positively related to host country's market size. They conclude that both countries’ FDI are attracted to locations with large market size.

Dynamic economy and appropriate economic growth policies are also crucial in order to attract FDI. Torrisi and Delaunay (2008) apply generalized least squares regression to identify the determinants of FDI in Central Europe and find that market size was a critical factor for FDI inflows during the economic transition period from 1989 to 2006. According to Quazi (2007), greater market size, measured by per capita real GDP, attracts more FDI in East Asia. Hailu's (2010) empirical analysis of the demand side determinants of FDI into African nations finds that the host country's market has statistically significant positive effect on FDI inflow. Kimino et al. (2007) on the other hand, find contradicting results in their research where there exists negative relationship between market size of source countries and FDI flows into Japan. Their result confirms that market size does not exert statistically significant influence on FDI into Japan, a developed country. This clearly shows that investors target local market besides the export market when undertaking FDI decisions.

Janicki and Wunnava (2004) find that the size of the market accurately reflects their theoretical expectations and confirm that market size is a significant determinant of FDI between members of the European Union. Based on their result, FDI flows are greater in larger economies with well-built markets. In addition, Bakir and Alfawwaz (2009) identify the determinants of foreign direct investments (FDI) in Jordan for the period 1996 to 2007 and confirm that GDP is positively related to FDI. The important role of market size in terms of GDP is found to significantly affect the volume of FDI flow to Jordan. Kim and Rhe (2009) also explore the trends as well as determinants of South Korean FDI and find that South Korean investors prefer larger markets and strategic assets.

A study by Russ (2007) on the endogeneity of the exchange rate as a determinant of FDI indicates that the variance of the exchange rate presents an impact towards the decision by multinational companies (MNC) to enter a particular market. Artige and Nicolini (2006) study the euro-effect on FDI for three European countries and conclude that exchange rate (euro currency) is an important criterion to attract foreign investors to these regions. Erdal and Tatoglu (2002) find that the instability of exchange rates has a negative relationship with FDI inflows. Their study investigates the case of Turkey whereby a highly volatile currency would discourage foreign investments.

Vogiatzoglou (2007) investigates the location determinants of inward FDI in South and East Asia find that if the degree of integration of the host country to the international economy rises, inward FDI also increases in the long run. Trade openness therefore has significantly positive effect on FDI. In addition, Agosin and Machado (2007) develop an ordinal index in order to measure the openness of FDI policy regimes in developing countries and find that openness is a factor that permits FDI. Aw 
and Tang (2010) as well as Oladipo (2010) find that trade openness has significant positive effect on trade and investments. Their results suggest that liberalization in Nigeria has significant impact on the economy with higher levels of exports due to a more flexible trade policy. Similarly, Ho and Rashid (2011) on ASEAN also find that trade openness is significant in attracting FDI.

In a recent study, Rehman and Raza (2011) apply export of goods and services as a percentage of GDP as a proxy to measure trade openness in Pakistan and find that trade openness has negative significant impact on FDI flow in Pakistan. Another study by Sekkat and Veganzones-Varoudakis (2007) assess the importance of openness in developing countries and find that increased openness as well as improvement in the other aspects of investment have contributed greatly in attracting FDI. Their result indicates that efforts towards openness should be initiated or further strengthened in order to make economies attractive to foreign investors. In contrast, Vijayakumar and Sridharan (2010) find no significant effect of trade openness on FDI inflows in BRICS countries. They suggest that trade openness may not be a crucial factor in attracting FDI inflows to these fast emerging countries. Similarly, Mateev (2009) identifies several key determinants of FDI flows into transition economies of Central and South-Eastern Europe and indicates that trade openness is statistically insignificant.

Borensztein, et al. (1998) test the relations of foreign direct investment (FDI) and economic growth in sixty-nine developing countries and show that financial development has insignificant effect on FDI. Woo (2009) investigates the effect of FDI on Total Factor Productivity (TFP) growth in a large sample of countries from 1970 to 2000 and confirms that financial development is positively associated with FDI. Oladipo (2010) identifies the determinants of foreign direct investment flow in a small open economy and finds that the level of financial development had negative implication on the growth FDI. It is surprising to note that financial development may not necessary induce FDI in smaller economies. Another study by Wang and Wong (2009) find complementary relation between financial depth and FDI and when financial depth increases, FDI growth increases but at a decreasing rate.

A country's exchange rate indirectly determines the competitiveness of its production. Some studies show that the stability of a host country's currency value attracts more foreign investment into host country (Rogoff and Reinhart, 2003; Brzozowski, 2006; Ho and Rashid, 2011). Alba, et al. (2009) also examines the impact of exchange rates in the United States (U.S.) and finds mixed results. MacDermott (2008) determines the relationship between the volatility in exchange rate and FDI and indicates that devaluation of the home currency would lead to a fall in FDI. In addition, volatility in exchange rate discourages foreign investor to invest in a host country and a favorable FDI environment is therefore vital for FDI inflows. 
Inflation affects prices of a country's produce and therefore directly affects trade and investment. Hailu (2010) finds that inflation has negative relation with FDI. When inflation rate increases, FDI decreases. Al-Nasser (2007) also finds that inflation is an important determinant of FDI with statistically significant negative relationship. A panel data analysis on location determinants of Chinese and Indian foreign directs investment by Duanmu and Guney (2009) find that inflation has insignificant relationship towards FDI. In addition, Gast and Herrmann (2008) identify the determinants of foreign direct investment for Organization of Economic Cooperation and Development (OECD) countries from 1991 to 2001 and find that inflation is negatively related to FDI. Wijeweera, et al. (2010) suggest that when government increases its spending towards education, quality of human capital improves and results in increasing FDI inflows. Kyrkilis and Pantelidis (2003) conclude that interest rate is statistically significant in affecting FDI in Italy, the Netherlands and Korea.

\section{Country Specific Factors}

Some researchers have applied economic freedom index as a determinant for FDI inflows and empirical evidence indicates that there is a positive significant relationship between this index and economic growth (Ayal and Karras, 1998; Heckelman, 2000). According to the Heritage Foundation, ${ }^{1}$ economic freedom is defined as the fundamental rights of every human to control his or her own labor and property. In addition to researching the relation between economic growth and economic freedom, researches have also employed economic freedom as a variable in FDI. Quazi (2007) indicates that a host country should formulate its FDI strategies by focusing on economic freedom components in order to attract more FDI inflow into the country. According to Caetano and Caleiro (2009) the risk perceived by investors is crucial in their decision to invest especially when it concerns a particular foreign country. Prior results indicate that economic freedom and FDI are positively related.

The literature that examines the relation between FDI, wages and productivity of a host country has found empirical evidence that host country with more conducive environment for FDI in terms of fixed entry cost and lower wages tend to attract more foreign investor (Lipsey and Sjoholm, 2010; Hayakawa, et al. 2010). Jensen and Rosas (2007) find that FDI and wages in Mexico are positively significant. Mexico is among the fast emerging countries where labour rate is still very low relative to other emerging countries and therefore it could still attract foreign investments into the country with increasing wage rate. Moreover, Blanton and Blanton (2007) find that foreign investors prefer countries with not only well trained and skilled labor but also low cost of wages.

\footnotetext{
${ }^{1}$ The Heritage Foundation is the official website that provides information on the world economic freedom. The organization works with Wall Street Journal to monitor the movements of economic freedom around the world. Their result is released via the Economic Freedom Index.
} 
According to Suh and Boggs (2011), ICT infrastructure has positive significant relation with investments in developed market but the results are insignificant in recent years. Hailu (2010) also shows that infrastructure is positively related to FDI flows in African countries. Al-Nasser (2007) confirms that infrastructure is one of the important factors in attracting foreign investor in Latin America and Asia. In contrast, Quazi (2007) finds insignificant relation between infrastructure and FDI in East Asia. Similar to Vijayakumar, et al. (2010), Rehman and Raza (2011) also find positively significant relation between infrastructure and FDI for Pakistan, and Zhang (2001) for China. Again, similar to Gast and Herrman (2008) on OECD countries, Hailu (2010) finds that human capital has insignificant effect on FDI in Africa. Further, Kyrkilis and Pantelidis (2003) and Blanton and Blanton (2007) also indicate that human capital has positive effect on FDI flows into non-OECD countries.

\section{Data and Methodology}

Annual data from 1977 to 2010 for Brazil, Russia, China, India, South Africa and Malaysia are from IMF International Financial Statistics (IFS), and Department of Statistics and Central Bank of each country. Economic freedom index is from the Heritage Foundation. Eleven variables that consist of macroeconomic fundamentals and country specific variables are designated as independent variables. The changes in the variables are computed and are used in the analysis in order to avoid spurious correlations.

Four techniques including OLS, seemingly unrelated regression (SUR), fixed country effect panel, and Granger-causality tests are applied in order to determine significant results. Panel data analysis uncovers dynamic relationships and blends intercountry differences and intracountry dynamics with both cross-sectional and time-series data. It provides more accurate inferences of model parameters wih less multicollinearity problems and hence improve the efficiency of econometric estimates while taking into account individual country effects. Fixed effect panel model using Generalized Least Square (GLS) produces robust estimates.

Macroeconomic fundamentals include market size, trade openness, financial development, exchange rate, interest rate, government consumption and inflation rate. These are used under the label of Model 1. The country specific variables are economic freedom, wages, human capital, and infrastructure quality. These enter into the analysis labeled as Model 2. The list of variables and their proxies are included in Table 1.

Macroeconomic Fundamentals (Model 1)

$$
F D I_{i t}=\alpha_{0}+\beta_{1} G D P_{i t}+\beta_{2} O P E N_{i t}+\beta_{3} F_{i n D e p t h}+\beta_{4} E R_{i t}+\beta_{5} I R_{i t}+\beta_{6} I F R_{i t}+\beta_{7} G O V_{i t}+\varepsilon
$$


Country Specific Factors (Model 2)

$$
F D I_{i t}=a_{0}+\lambda_{1} W_{i t}+\lambda_{2} F R E E_{i t}+\lambda_{3} L R_{i t}+\lambda_{4} I N Q_{i t}+\delta
$$

Table 1: Proxy of each Variable and Expected Relationship with FDI Inflow

\begin{tabular}{|l|l|c|}
\hline Variables & Proxy & Expected Relationship \\
\hline Total Foreign Direct Investment (FDI) & Annual FDI & Positive \\
\hline Market Size (GDP) & Annual GDP & Positive \\
\hline Trade Openness (OPEN) & $(\mathrm{x}+$ m) / GDP & Positive \\
\hline Financial Development (FIN DEPTH) & M2/GDP & Negative \\
\hline Exchange Rate (ER) & Exchange Rate/US Dollar & Negative \\
\hline Interest Rate (IR) & Annual Interest Rate & Negative \\
\hline Government Consumption (GOV) & Government Consumption & Positive \\
\hline Inflation Rate (IFR) & Consumer Price Index & Negative \\
\hline Wages (W) & \% of total Employed & Positive \\
\hline Human Capital (LR) & Literacy Rate & Positive \\
\hline Economic Freedom (FREE) & Index Economic Freedom & Positive \\
\hline Infrastructure Quality (INQ) & Log per capita Electricity & \\
\hline
\end{tabular}

Both Augmented Dickey-Fuller (ADF) and Kwiatkowski-Phillips-Schmidt-Shin (KPSS) unit root tests for individual countries as well as panel unit root tests are applied in order to check for robustness of the time series. Panel unit root test results are shown in Table $2 .^{2}$ All the macroeconomic fundamental and country specific time series are transformed to ensure there is no unit-root problem and that all the time series used in the tests are stationary.

Table 2: Panel Unit Root Test Results

\begin{tabular}{|c|r|r|r|r|}
\hline & $\begin{array}{c}\text { Levin, Lin \& Chu } \\
\text { t* }\end{array}$ & $\begin{array}{c}\text { Im, Pesaran and } \\
\text { Shin W-stat }\end{array}$ & $\begin{array}{c}\text { ADF - Fisher Chi- } \\
\text { square }\end{array}$ & $\begin{array}{c}\text { PP - Fisher Chi- } \\
\text { square }\end{array}$ \\
\hline FDI & 589.196 & $-7.04907^{*}$ & $70.2228^{*}$ & $101.423^{*}$ \\
\hline GDP & $-5.79735^{*}$ & $-4.92477^{*}$ & $47.2639^{*}$ & $63.5560^{*}$ \\
\hline OPEN & $-5.63255^{*}$ & $-5.38188^{*}$ & $51.3382^{*}$ & $86.8010^{*}$ \\
\hline FIN DEPTH & $-5.84644^{*}$ & $-4.98788^{*}$ & $51.2975^{*}$ & $85.6724^{*}$ \\
\hline ER & -0.44364 & $-4.53172^{*}$ & $44.2583^{*}$ & $281.100^{*}$ \\
\hline GOV & $-4.82138^{*}$ & $-4.23113^{*}$ & $40.0638^{*}$ & $60.6726^{*}$ \\
\hline IFR & -1.04584 & $-3.94876^{*}$ & $38.2805^{*}$ & $162.164^{*}$ \\
\hline IR & $-3.87420^{*}$ & $-7.18459^{*}$ & $72.2365^{*}$ & $119.459^{*}$ \\
\hline W & $-1.600145^{* *}$ & $-3.71962^{*}$ & $37.1395^{*}$ & $67.6616^{*}$ \\
\hline LR & 56.1898 & $-2.14977^{* *}$ & $30.6987^{*}$ & $70.6587^{*}$ \\
\hline FREE & $-4.36504^{*}$ & $-3.57767^{*}$ & $35.2047^{*}$ & $76.8976^{*}$ \\
\hline INQ & $-30.5461^{*}$ & $-15.5459^{*}$ & $48.7461^{*}$ & $96.9415^{*}$ \\
\hline
\end{tabular}

Note: LLC, IPS and ADF and PP-Fisher tests have null hypothesis of the existence of a unit root in any of the series in the panel. Probabilities for Fisher tests are computed using an asympotic Chi-square distribution. All other tests assume asymptotic normality. For a group or pool unit root test, the EViews default is to use automatic selection methods: information matrix criterion based for the number of lag difference terms (with automatic selection of the maximum lag to evaluate), and the Newey-West method for bandwidth selection. *, ** and *** denote statistical significance at 1,5 and $10 \%$.

\section{Findings and Interpretation}

Individual results for Models 1 and 2 on fundamental and country specific factors are included in Tables 3 and 4 .

\footnotetext{
${ }^{2}$ Detailed individual country unit root test results are available from the authors.
} 
The results for Brazil show that there is marginally significant positive relation between interest rate and FDI. An increase in the country's interest rates would result in an increase in the country's FDI. Besides that, positive relation is also found between FDI and financial depth, trade openness, economic growth, government consumption and exchange rate.

The overall result for country specific variables in Model 2 is statistically significant (Probability of f-significance of 0.074). The results for Brazil show that economic freedom and infrastructure quality (INQ) have statistically significant positive relation with FDI. Improvement in domestic infrastructure and policies to allow more freedom to make decisions would improve the potential for attracting foreign investments into host countries.

Table 3: Macroeconomic factors and FDI inflow for BRICS

\begin{tabular}{|c|c|c|c|c|c|c|}
\hline Variables & Brazil & Russia & India & China & S Africa & Malaysia \\
\hline \multirow{2}{*}{$\mathrm{C}$} & 0.088 & 0.328 & -0.126 & --0.296 & 4.058 & -1.438 \\
& $(0.738)$ & $(0.169)$ & $(0.678)$ & $(0.417)$ & $(0.675)$ & $(0.034)^{* *}$ \\
\hline \multirow{2}{*}{ GDP } & 0.057 & 4.156 & 3.524 & 5.217 & 27.211 & 15.424 \\
& $(0.981)$ & $(0.016)^{* *}$ & $(0.409)$ & $(0.095)^{*}$ & $(0.667)$ & $(0.0215)^{* *}$ \\
\hline \multirow{2}{*}{ OPEN } & 2.246 & 0.961 & 2.235 & 0.0735 & -9.718 & 6.8678 \\
& $(0.287)$ & $(0.595)$ & $(0.118)$ & $(0.931)$ & $(0.788)$ & $(0.087)^{*}$ \\
\hline \multirow{2}{*}{ FIN DEPTH } & 0.205 & & -0.582 & 0.313 & 0.090 & 3.641 \\
& $(0.774)$ & - & $(0.366)$ & $(0.315)$ & $(0.997)$ & $(0.432)$ \\
\hline \multirow{2}{*}{ IFR } & -0.020 & -0.425 & 0.203 & -1.771 & -90.133 & 7.252 \\
& $(0.939)$ & $(0.162)$ & $(0.964)$ & $(0.595)$ & $(0.367)$ & $(0.712)$ \\
\hline \multirow{2}{*}{ GOV } & 1.431 & -4.521 & -0.545 & -2.438 & -34.447 & -6.756 \\
& $(0.505)$ & $(0.021)^{* *}$ & $(0.873)$ & $(0.109)$ & $(0.578)$ & $(0.163)$ \\
\hline \multirow{2}{*}{ IR } & 0.984 & 0.259 & 1.158 & -0.477 & -8.862 & -0.837 \\
& $(0.085)^{*}$ & $(0.568)$ & $(0.376)$ & $(0.060)^{*}$ & $(0.659)^{* *}$ & $(0.784)$ \\
\hline \multirow{2}{*}{ ER } & -0.011 & -0.239 & 4.493 & 4.387 & - & - \\
& $(0.692)$ & $(0.616)$ & $(0.004)^{* * *}$ & $(0.163)$ & & \\
\hline Adjusted R2 & 0.035 & 0.435 & 0.001 & 0.527 & 0.001 & 0.460 \\
\hline F-significance & 0.383 & $0.089^{*}$ & 0.500 & $0.041^{* *}$ & 0.950 & $0.008^{* * *}$ \\
\hline
\end{tabular}

Note: * indicates $10 \%$ significant level, **5\% significant level, and ***1\% significant levels.

Market size (GDP) and government expenditure are significant in affecting FDI flows for Russia where the potential of a large market for goods and services is a vital factor in attracting investments. The overall model for Russia is also statistically significant in explaining FDI into Russia. Government consumption has negative effect on FDI where contractionary fiscal policy is inversely related to foreign investments and foreigners perceive higher government consumption as detrimental to investments. Financial depth is excluded in Model 1 for Russia due to multicollinearity effects with GDP, and robustness test performed confirm that it is not significant in affecting FDI. In addition, results for Model 2 verify that literacy rate and infrastructure quality are important considerations for foreign investment. Improvement in accessibility to markets and export destinations would encourage investors locating themselves in certain geographically challenged areas. 
Based on theoretical expectation, exchange rate is significant in affecting FDI decisions in India. The results however suggest that a fall in the currency value would encourage foreign investors into India. The results for country specific factors are not significant, though there exists positive relation between FDI, wages and infrastructure, and negative relation between FDI, literacy rate and economic freedom.

The model for China is statistically significant and affirms that market size is significant in affecting FDI flows. Foreign investors seeking new markets in China are attracted by the potential of a large market size. In recent years, China has attracted a substantial amount of FDI which enable the economy to grow at tremendous rate relative to the rate of world growth. In addition, interest rate is another macroeconomic fundamental that possess significant relation with FDI in this country where increase in interest rates which increase production costs discourages foreign investments. Significant relations are also found for employment, infrastructure and economic freedom for country specific model for China in Model 2. Higher employment and therefore indirectly higher cost of labor is found to discourage foreign investments in China. The economic freedom index is found to be negatively related to FDI where freedom in decisions would probably reduce the power of foreign firms in dictating the market. This scenario is typically found in newly open economies but not the others. Similar to other fast emerging countries, infrastructure improvements would enable foreign organizations to move their goods to market efficiently and this would encourage FDI across all countries dictating positive relationship. The f-statistics for the China model is also statistically significant.

Table 4: Country Specific factors and FDI inflow for BRICS

\begin{tabular}{|c|c|c|c|c|c|c|}
\hline Variables & Brazil & Russia & India & China & S Africa & Malaysia \\
\hline \multirow{2}{*}{ Constant } & -0.209 & 0.364 & 0.157 & -0.086 & -6.955 & 1.811 \\
& $(0.383)$ & $(0.046)^{* *}$ & $(0.725)$ & $(0.477)$ & $(0.136)$ & $(0.162)$ \\
\hline \multirow{2}{*}{$\mathrm{W}$} & 5.957 & 0.401 & 0.433 & -0.796 & 31.373 & -14.956 \\
& $(0.113)$ & $(0.409)$ & $(0.166)$ & $(0.015)^{* *}$ & $(0.500)$ & $(0.140)$ \\
\hline \multirow{2}{*}{ LR } & -10.128 & -652.1 & -1.233 & -1.4137 & 474.640 & 347.944 \\
& $(0.771)$ & $(0.028)^{* *}$ & $(0.942)$ & $(0.760)$ & $(0.005)^{* * *}$ & $(0.301)$ \\
\hline \multirow{2}{*}{ INQ } & 7.083 & 2.335 & 1.342 & 2.384 & 12.024 & 19.923 \\
& $(0.015)^{* *}$ & $(0.007)^{* * *}$ & $(0.879)$ & $(0.023)^{* *}$ & $(0.072)^{* *}$ & $(0.028)^{* *}$ \\
\hline \multirow{2}{*}{ FREE } & 2.673 & 3.470 & -4.194 & -1.520 & -72.735 & 34.763 \\
& $(0.066)^{*}$ & $(0.111)$ & $(0.316)$ & $(0.012)^{* *}$ & $(0.144)$ & $(0.065)^{*}$ \\
\hline Adjusted R2 & 0.359 & 0.214 & 0.001 & 0.405 & 0.001 & 0.326 \\
\hline F-significance & $0.074 *$ & 0.218 & 0.787 & $0.053^{*}$ & 0.506 & $0.092^{*}$ \\
\hline
\end{tabular}

Note: *10\% significant level, **5\% significant level, ***1\% significant level

Interest rate is the only macroeconomic fundamental that significantly affect FDI in South Africa. Fast emerging countries including China and South Africa find that increasing interest rate increases the cost of doing business and discourages not only foreign investments but also domestic investments. Education is a significant driver of investments when skilled and knowledgeable 
workforce improves productivity and reduces costs in South Africa. In addition, infrastructure improvements also enable emerging countries to accelerate growth and boost productivity through foreign investments.

It is important to note that market size is a significant factor in attracting FDI into emerging countries including Russia, China and Malaysia where the models tested are statically significant. Openness to trade indicated by export and import activities enables foreign investors to distribute their goods not only in the domestic economy but also to neighboring markets which may not be attractive for production facilities. Trade openness is found to be significant to Malaysia only but not to the other fast emerging countries and the overall model is statistically significant. There is generally positive relation between trade openness and FDI in emerging markets. The set of country specific factors which is positively significant for Malaysia include infrastructure and economic freedom and the model is statistically significant. Similar to the other fast emerging countries, positive significant effect of improvement in infrastructure in attracting FDI is also found for Malaysia. This underscores the findings for fast emerging countries and justifies additional government expenditure on infrastructure to improve not only domestic logistics but also increasing the development of the domestic economy through foreign investments.

The results of the seemingly unrelated regression (SUR) and fixed effect panel data analyses are shown in Table 5. The significance and robustness of both macroeconomic fundamentals and country specific determinants of FDI into BRICS and Malaysia are verified in the reults. There is significant relation between market size, trade openness, government consumption and FDI for this group of emerging economies. The larger the market potential, the more attractive it is for multinational companies' investment due to larger demand, which in turn enables production to achieve cost advantage through economies of scale. Attractive trade policy that enables openness to trade in not only imports of capital and raw materials but also exports of finished products to nearby regions would also result in higher level of FDI. In addition, responsible government management in consumption and taxation are also magnets for foreign investments. It is important to note that all the SUR and panel models are statistically significant in driving FDI inflows for this group of country as a whole.

The analyses also suggest that infrastructure quality and economic freedom are significant country specific determinants of FDI in Model 2. Multinational companies aim to invest in countries that would enable them to take advantage of not only the market potential with responsible governments but also countries where they can smoothly operate their business with ease. One major attributes they seek is the ability of the host country to support infrastructure development which would prevent logistics issues. Developing countries are therefore allocating a large budget for 
improving their respective infrastructure not only for domestic economic development but also to attract foreign investments.

Future studies should also include other variables to investigate FDI in addition to those included in this study. In summary, the results are consistent and robust from both the individual and panel data analyses.

Table 5: SUR and Fixed Effect Analysis of FDI in BRICS and Malaysia

\begin{tabular}{|c|c|c|c|c|}
\hline & \multicolumn{2}{|c|}{ SUR } & \multicolumn{2}{|c|}{ Fixed Effect } \\
\hline & Model 1 & Model 2 & Model 1 & Model 2 \\
\hline GDP & $\begin{array}{c}4.031 \\
(0.001)^{* * *}\end{array}$ & & $\begin{array}{c}3.139 \\
(0.000)^{* * *}\end{array}$ & \\
\hline OPEN & $\begin{array}{c}3.376 \\
(0.005)^{* * *}\end{array}$ & & $\begin{array}{c}1.195 \\
(0.063)^{*}\end{array}$ & \\
\hline $\begin{array}{l}\text { FIN } \\
\text { DEPTH }\end{array}$ & $\begin{array}{c}0.641 \\
(0.347)\end{array}$ & & $\begin{array}{c}-0.006 \\
(0.985)\end{array}$ & \\
\hline IFR & $\begin{array}{c}-0.003 \\
(0.995)\end{array}$ & & $\begin{array}{l}-0.036 \\
(0.875)\end{array}$ & \\
\hline GOV & $\begin{array}{c}-1.402 \\
(0.215)\end{array}$ & & $\begin{array}{c}-1.646 \\
(0.024)^{* *}\end{array}$ & \\
\hline IR & $\begin{array}{c}0.127 \\
(0.841) \\
\end{array}$ & & $\begin{array}{c}0.438 \\
(0.202) \\
\end{array}$ & \\
\hline ER & $\begin{array}{r}0.022 \\
(0.623) \\
\end{array}$ & & $\begin{array}{c}0.001 \\
(0.967)\end{array}$ & \\
\hline W & & $\begin{array}{c}0.513 \\
(0.121) \\
\end{array}$ & & $\begin{array}{c}-0.093 \\
(0.791) \\
\end{array}$ \\
\hline LR & & $\begin{array}{l}-4.053 \\
(0.507)\end{array}$ & & $\begin{array}{l}-3.377 \\
(0.495)\end{array}$ \\
\hline INQ & & $\begin{array}{c}1.269 \\
(0.081)^{*}\end{array}$ & & $\begin{array}{c}2.466 \\
(0.002)^{*}\end{array}$ \\
\hline FREE & & $\begin{array}{c}0.422 \\
(0.716)\end{array}$ & & $\begin{array}{c}-1.739 \\
(0.058)^{*}\end{array}$ \\
\hline Constant & $\begin{array}{c}-0.531 \\
(0.020)^{* *}\end{array}$ & $\begin{array}{l}-0.127 \\
(0.296)\end{array}$ & $\begin{array}{c}-0.858 \\
(0.000)^{* * *}\end{array}$ & $\begin{array}{c}-0.309 \\
(0.000)^{* * *}\end{array}$ \\
\hline Adjusted $\mathrm{R}^{2}$ & 0.114 & 0.073 & 0.157 & 0.133 \\
\hline F-prob & $0.004 * * *$ & $0.036 * *$ & $0.002 * * *$ & $0.015 * *$ \\
\hline
\end{tabular}

Note: * is $10 \%$ significant level, ** $5 \%$ significant level, and $* * * 1 \%$ significant levels

Table 6 provides the results of Granger causality tests. There is evidence to support market size granger cause FDI in Brazil, Russia and China. This confirms that market size plays a vital role in attracting foreign investment into these countries. Trade openness is also found to granger cause FDI in Brazil where open flow of trade attracts investments into the country. Financial depth is found to granger cause FDI in China where FDI is attracted by financial market development in the country where liquidity and financing would not pose any problem. In addition, interest rate is found to granger cause FDI in Malaysia where foreign investors are very sensitive to financial costs when making investment decisions.

There is also some evidence that FDI granger cause inflation and exchange rate in China. FDI granger cause government consumption in India, and interest rate changes in Brazil and Russia. For 
the set of country specific factors, there is evidence to conclude that employment granger cause FDI in Russia, and infrastructure quality granger cause FDI in China. In addition, it is also found that FDI granger cause education in Russia and labor cost in Malaysia.

Table 6: Granger Causality Results for Model 1 and 2

\begin{tabular}{|c|c|c|c|c|c|c|c|}
\hline & Brazil & Russia & India & China & S Africa & Msia & Panel \\
\hline GDP does not Granger cause FDI & $\begin{array}{l}2.652 \\
0.092 *\end{array}$ & $\begin{array}{l}4.107 \\
0.042 * *\end{array}$ & $\begin{array}{l}0.783 \\
0.468 \\
\end{array}$ & $\begin{array}{l}3.910 \\
0.035 * *\end{array}$ & $\begin{array}{l}0.356 \\
0.704 \\
\end{array}$ & $\begin{array}{l}0.362 \\
0.699 \\
\end{array}$ & $\begin{array}{l}0.089 \\
0.915\end{array}$ \\
\hline $\begin{array}{l}\text { OPEN does not Granger cause } \\
\text { FDI }\end{array}$ & $\begin{array}{l}5.596 \\
0.011^{* *}\end{array}$ & $\begin{array}{l}0.378 \\
0.695 \\
\end{array}$ & $\begin{array}{l}0.786 \\
0.467 \\
\end{array}$ & $\begin{array}{l}1.079 \\
0.358 \\
\end{array}$ & $\begin{array}{l}1.046 \\
0.367\end{array}$ & $\begin{array}{l}1.559 \\
0.233\end{array}$ & $\begin{array}{l}1.418 \\
0.246\end{array}$ \\
\hline FIND does not Granger cause FDI & $\begin{array}{l}0.739 \\
0.488\end{array}$ & $\begin{array}{l}0.924 \\
0.519\end{array}$ & $\begin{array}{l}1.113 \\
0.363\end{array}$ & $\begin{array}{l}4.366 \\
0.040 * *\end{array}$ & $\begin{array}{l}0.066 \\
0.936\end{array}$ & $\begin{array}{l}1.207 \\
0.322\end{array}$ & $\begin{array}{l}0.059 \\
0.943\end{array}$ \\
\hline FDI does not Granger cause IFR & $\begin{array}{l}0.593 \\
0.560\end{array}$ & $\begin{array}{l}0.189 \\
0.829 \\
\end{array}$ & $\begin{array}{l}1.788 \\
0.189 \\
\end{array}$ & $\begin{array}{l}2.731 \\
0.086^{*}\end{array}$ & $\begin{array}{l}0.531 \\
0.595\end{array}$ & $\begin{array}{l}1.864 \\
0.178 \\
\end{array}$ & $\begin{array}{l}0.018 \\
0.982 \\
\end{array}$ \\
\hline GOV does not Granger cause FDI & $\begin{array}{l}3.005 \\
0.070 *\end{array}$ & $\begin{array}{l}0.043 \\
0.958 \\
\end{array}$ & $\begin{array}{l}0.893 \\
0.424 \\
\end{array}$ & $\begin{array}{l}0.172 \\
0.843 \\
\end{array}$ & $\begin{array}{l}0.416 \\
0.665 \\
\end{array}$ & $\begin{array}{l}0.784 \\
0.469 \\
\end{array}$ & $\begin{array}{l}0.602 \\
0.549 \\
\end{array}$ \\
\hline FDI does not Granger cause GOV & $\begin{array}{l}0.402 \\
0.674\end{array}$ & $\begin{array}{l}1.375 \\
0.285\end{array}$ & $\begin{array}{l}3.480 \\
0.049 * *\end{array}$ & $\begin{array}{l}0.074 \\
0.929\end{array}$ & $\begin{array}{l}0.038 \\
0.962\end{array}$ & $\begin{array}{l}0.144 \\
0.867\end{array}$ & $\begin{array}{l}0.237 \\
0.789\end{array}$ \\
\hline IR does not Granger cause FDI & $\begin{array}{l}0.778 \\
0.472 \\
\end{array}$ & $\begin{array}{l}1.515 \\
0.256\end{array}$ & $\begin{array}{l}0.083 \\
0.921\end{array}$ & $\begin{array}{l}1.723 \\
0.203 \\
\end{array}$ & $\begin{array}{l}0.138 \\
0.871 \\
\end{array}$ & $\begin{array}{l}3.426 \\
0.050 \text { ** }\end{array}$ & $\begin{array}{l}0.017 \\
0.983 \\
\end{array}$ \\
\hline FDI does not Granger cause IR & $\begin{array}{l}4.042 \\
0.032 * *\end{array}$ & $\begin{array}{l}3.182 \\
0.075 *\end{array}$ & $\begin{array}{l}0.461 \\
0.637 \\
\end{array}$ & $\begin{array}{l}0.139 \\
0.871 \\
\end{array}$ & $\begin{array}{l}1.278 \\
0.298 \\
\end{array}$ & $\begin{array}{l}0.098 \\
0.392 \\
\end{array}$ & $\begin{array}{l}1.026 \\
0.361 \\
\end{array}$ \\
\hline FDI does not Granger cause ER & $\begin{array}{l}0.833 \\
0.186\end{array}$ & $\begin{array}{l}0.689 \\
0.524 \\
\end{array}$ & $\begin{array}{l}0.700 \\
0.506 \\
\end{array}$ & $\begin{array}{l}6.501 \\
0.005^{* * *}\end{array}$ & $\begin{array}{l}0.372 \\
0.693 \\
\end{array}$ & $\begin{array}{l}0.657 \\
0.527 \\
\end{array}$ & $\begin{array}{l}0.006 \\
0.994 \\
\end{array}$ \\
\hline W does not Granger cause FDI & $\begin{array}{l}0.765 \\
0.494 \\
\end{array}$ & $\begin{array}{l}11.787 \\
0.008 * * *\end{array}$ & $\begin{array}{l}0.187 \\
0.831 \\
\end{array}$ & $\begin{array}{l}1.504 \\
0.243 \\
\end{array}$ & $\begin{array}{l}2.622 \\
0.111 \\
\end{array}$ & $\begin{array}{l}0.489 \\
0.619 \\
\end{array}$ & $\begin{array}{l}0.350 \\
0.705 \\
\end{array}$ \\
\hline FDI does not Granger cause W & $\begin{array}{l}1.410 \\
0.293\end{array}$ & $\begin{array}{l}0.789 \\
0.496 \\
\end{array}$ & $\begin{array}{l}0.228 \\
0.797 \\
\end{array}$ & $\begin{array}{l}2.408 \\
0.111 \\
\end{array}$ & $\begin{array}{l}0.456 \\
0.644\end{array}$ & $\begin{array}{l}2.866 \\
0.078 *\end{array}$ & $\begin{array}{l}0.132 \\
0.876\end{array}$ \\
\hline FDI does not Granger cause LR & $\begin{array}{l}0.240 \\
0.789 \\
\end{array}$ & $\begin{array}{l}2.549 \\
0.100 *\end{array}$ & $\begin{array}{l}0.613 \\
0.551 \\
\end{array}$ & $\begin{array}{l}0.895 \\
0.422 \\
\end{array}$ & $\begin{array}{l}0.276 \\
0.761 \\
\end{array}$ & $\begin{array}{l}1.116 \\
0.344 \\
\end{array}$ & $\begin{array}{l}0.075 \\
0.928 \\
\end{array}$ \\
\hline INQ does not Granger cause FDI & $\begin{array}{l}1.478 \\
0.246 \\
\end{array}$ & $\begin{array}{l}0.687 \\
0.521 \\
\end{array}$ & $\begin{array}{l}0.447 \\
0.644 \\
\end{array}$ & $\begin{array}{l}9.715 \\
0.001 * * *\end{array}$ & $\begin{array}{l}0.034 \\
0.966 \\
\end{array}$ & $\begin{array}{l}0.560 \\
0.580\end{array}$ & $\begin{array}{l}0.509 \\
0.602 \\
\end{array}$ \\
\hline
\end{tabular}

Note: * indicates $10 \%$ significant level, ** 5\% significant level, and ***1\% significant levels.

In summary, Granger causality tests confirm that there are significant causality effects from market size, trade openness, financial development, government consumption and interest rate to FDI of emerging countries. In addition, for the country specific model, employment and infrastructure quality are found to granger cause FDI in BRICS and Malaysia.

\section{Conclusion}

This study provides empirical evidence for the determinants of FDI in BRICS and Malaysia using individual country analyses, seemingly unrelated and panel regressions, and granger causality tests over the period of 1977 to 2010. Most of our findings are theoretically supported and statistically significant. Economic freedom is a novel variable that is considered and it is found to be statistically significant. Findings from this research add new knowledge to the understanding of FDI flows into 
fast emerging countries. In addition, the results are expected to assist emerging nations to strategize policies for managing FDI flows.

The findings suggest that trade openness, economic growth, government expenditure, infrastructure quality are the most critical factors in determining FDI flows in BRICS and Malaysia. We also note with interest that economic freedom is found to significantly affect FDI in Brazil, China and Malaysia. Prior literature on economic freedom has also found significant relation with FDI inflows. Further, and again in line with prior studies, an increase in a country's trade openness seem to exert positive effect on FDI inflow.

Different factors might affect the countries differently and some factors may be more significant in one country than others. This study has found significant positive relation between infrastructure quality and FDI flows in Brazil, Russia, China, South Africa and Malaysia. This variable is one of the critical country specific determinants of FDI flows.

The results of SUR and fixed effect panel models indicate that economic growth, openness, infrastructure quality and economic freedom are important for FDI flows. Robustness tests confirm the significance of these factors for both Models 1 and 2. In addition, granger causality tests also indicate that economic growth, trade openness, government consumption, and interest rate granger caused FDI in some countries. For the country specific factors, wage rate and infrastructure quality granger cause FDI flows in Russia and China, respectively.

Exploring other determinants is the subject for future research. Increasing the length of the data series, and improving theoretical modeling in line with the data are recommended. The accessibility and availability of other country specific variables would further stimulate interest in this area.

Authors Information: Catherine S F Ho is a professor at the Universiti Teknologi MARA, Shah Alam, Malaysia. Email: catherine@salam.uitm.edu.my Tel:603-5544-4792. She holds concurrent positions in the Institute of Business Excellence and Arshad Ayub Graduate Business School. Noryati Ahmad and Hayati Mohd. Dahan are also staff members at the Universiti Teknologi MARA. The authors acknowledge the research assistance provided by Khairunnisa Amir, Linda Nasaruddin Sia and Nurain Farahana Zainal Abidin. The authors acknowledge with thanks the editorial review suggestions and comments from the 2012 MFA conference as well as the useful editing of the paper by the Journal's co-editors. The authors alone are responsible for any error. 


\section{References}

Agosin, M. and Machado, R. (2007). Openness and the international allocation of foreign direct investment, Journal of Development Studies, 43(7), 1234-1247.

Al Nasser, O. (2007). The determinats of the U.S foreign direct investment: does the region matter? Global Economic Review, 36(1), 37-51.

Alba, J. D., Park, D., and Wang, P. (2009). The impact of exchange rate on FDI and the interdependence of FDI over time, ADB Economics Working Paper Series (164), 1-25.

Artige, L. and Nicolini, R. (2006). Evidence on the determinants of foreign direct investment: The case of three European regions, CREPP Working Paper 2006/07, Centre of Research in Public Economics and Population Economics, HEC-Management School, University of Liège.

Aw, T. and Tang, T. (2010). The determinants of inward foreign direct investment: The case of Malaysia, International Journal of Business and Society, 11(1), 59-76.

Ayal, B. E. \& Karras, G. (1998). Components of economic freedom and growth: an empirical study, Journal of Developing Areas, 32(3), 327-338.

Bakir, A. and Alfawwaz, T. (2009). Determinants of foreign direct investment in Jordan, International Management Review, 5(2), 66-73.

Blanton, S. L. and Blanton, R. G. (2007). What attracts foreign investors? An examination of human rights and foreign direct investment, The Journal of Politics, 69(1), 143-155.

Borensztein, E., Gregorio, J. and Lee, J. (1998). How does foreign direct investmenti affect economic growth? Journal of International Economics, 45(1), 115-135.

Brzozowski, M. (2006). Exchange rate variability and foreign direct investment: consequences of EMU enlargement, Eastern European Economics, 44(1), 5-24.

Caetano, J. and Caleiro, A. (2009). Economic freedom and foreign direct investment: How different are the MENA Countries from EU, iBusiness, 1(2), 65-74.

Duanmu, J. and Guney, Y. (2009). A panel data analysis of locational determinants of Chinese and Indian outward foreign direct investment, Journal of Asia Business Studies, 3(2), 1-15.

Erdal, F. and Tatoglu, E. (2002). Locational determinants of FDI in an emerging market economy: evidence from Turkey, Multinational Business Review, 10(1), 21-28.

Gast, M. and Herrmann, R. (2008). Determinants of foreign direct investment of OECD countries 1991-2001, International Economic Journal, 22(4), 509-524.

Hailu, Z. (2010). Demand side factors affecting the inflow of foreign direct investment to African countries: does capital market matter? International Journal of Business and Management, 5(5), 104-116.

Hayakawa, K., Lee, H. H. and Park, D. (2010). The role of home and host country characteristics in FDI: firm-level evidence from Japan, Korea and Taiwan, IDE Discussion Paper (267), 1-25.

Heckelman, J. C. (2000). Economic freedom and economic growth: A short-run causal investigation, Journal of Applied Economics, 3(1), 71-91.

Ho, C. S. F. and Rashid, A. H. M. (2011). Macroeconomic and country specific determinants of FDI, The Business Review Cambridge, 18(1), 219-234.

Janicki, H. and Wunnava, P. (2004). Determinants of foreign direct investment: empirical evidence from EU accession candidates, Applied Economics, 36(5), 505-509.

Jensen, N. M. and Rosas, G. (2007). Foreign direct investment and income inequality in Mexico 19902000, International Organization, 61(3), 467-487.

Kim, J. and Rhe, D. (2009). Trends and determinants of South Korean outward foreign direct investment, The Copanhagen Journal of Asian Studies, 27(1), 126-154.

Kimono, S., Saas, D. and Driffield, N. (2007). Macro determinants of FDI inflows to Japan: An analysis of sources country characteristics, The World Economy, 30(3), 446-469.

Kyrkilis, D. and Pantelidis, P. (2003). Macroeconomic determinants of outward foreign direct investment, International Journal of Social Economics, 30(7), 827-836.

Lipsey, R. E. and Sjoholm, F. (2010). FDI and growth in East Asia: Lessons for Indonesia. IFN Working Paper (852), 1-49. 
Lokesha, B. K. and Leelavathy, D. S. (2012). Determinants of foreign direct investment: A macro perspective, The Indian Journal of Industrial Relations, 47(3), 459-469.

MacDermott, R. (2008). Linking exchange eates to foreign direct investment, The International Trade Journal, 22(1), 3-16.

Mateev, M. (2009). Determinants of foreign direct investment in Central and Southeastern Europe, Oxford Journal, 8(1), 133-149.

Oladipo, O. (2010). Foreign direct investment: Determinants and growth effects in a small open economy, The International Journal of Business and Finance Research, 4(4), 75-88.

Quazi, R. (2007). Economic freedom and foreign direct investment in East Asia, Journal of the Asia Pacific Economy, 12(3), 329-344.

Rehman, A. and Raza, A. (2011). Determinants of foreign direct investment and its impact on GDP growth in Pakistan, Interdisciplinary Journal of Contemporary Research in Business, 2(9), 198205.

Rogoff, K.and Reinhart, C. (2003). FDI to Africa: The role of price stability and currency instability, IMF Working Paper 03/10.

Russ, K. N. (2007). The endogeneity of the exchange rate as a determinant of FDI: A model of entry and multinational firms, Journal of International Economics, 71(2), 344-372.

Sekkat, K. and Veganzones-Varoudakis, M. (2007). Openness, investment climate and FDI in developing countries, Review of Development Economics, 11(4), 607-620.

Suh, T. and Boggs, D. (2011). Communication infrastructure and traditional determinants of inward foreign investment: A comparison of developed and emerging markets, Competitiveness Review: An International Business Journal, 21 (2), 205-223.

Torrisi, C. and Delaunay, C. J. (2008). FDI in Central Europe: Determinants and policy implication, Journal of International Finance and Economics, 8(4), 136-147.

Vijayakumar, N. and Sridharan, P. (2010). Determinants of FDI in BRICS countries: A panel analysis. International Journal of Business Science and Applied Management, 5(3), 1-13.

Vogiatzoglou, K. (2007). Vertical specialization and new determinants of FDI: Evidence from South and East Asia, Global Economic Review, 36(3), 245-266.

Wang, M. and Wong, M. (2009). Foreign direct investment and economic growth: The growth accounting perspective, Economic Inquiry, 47(4), 701-710.

Wijeweera, A., Villano, R. and Dollery, B. (2010). Economic growth and FDI inflows: A stochastic frontier analysis, The Journal of Developing Areas, 43(2), 143-158.

Woo, J. (2009). Productivity growth and technological diffussion through foreign direct investment. Economic Inquiry, 47(2), 226-248.

Zhang, K. H. (2001). What attracts foreign multinational corporations to China? Contemporary Economic Policy, 19(3), 336-346. 